
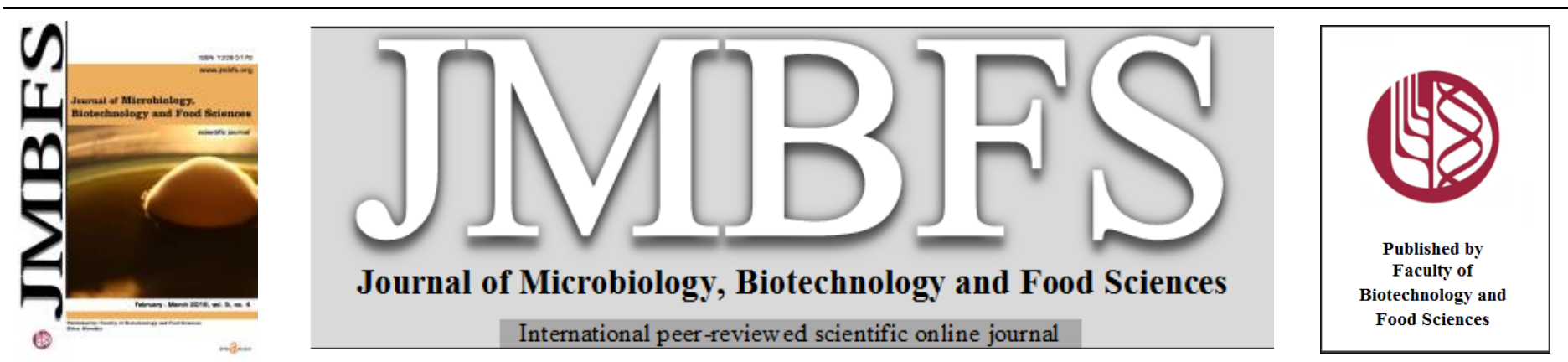

\title{
AMYLOLYTIC ACTIVITY OF KLUYVER-POSITIVE DEBARYOMYCES OCCIDENTALIS CELLS IMMOBILIZED IN FOAMED ALGINATE GEL
}

\author{
Dorota Kregiel \\ Address(es): Ass. prof. Dorota Kregiel, \\ Lodz University of Technology, Faculty of Biotechnology and Food Science, Institute of Fermentation Technology and Microbiology, Wolczanska 171/173, 90-924 \\ Lodz, Poland, +48 426313247.
}

*Corresponding author: dorota.kregiel@p.lodz.pl

doi: 10.15414/jmbfs.2016.5.4.311-313

\section{ARTICLE INFO}

Received 18. 8. 2015

Revised 9. 10. 2015

Accepted 22. 10. 2015

Published 1. 2. 2016

Short communication

OPEN $\partial$ ACCESS

\begin{abstract}
This study investigates the amylolytic activity of Kluyver-positive yeast strain Debaryomyces occidentalis immobilized in foamed alginate gels. Encapsulation was performed through the traditional process of droplet formation from a foamed alginate solution. The beads were coated with a layer of $3 \%$ alginate. Amylolytic enzyme activities were determined in the presence of different carbon sources - glucose, maltose, starch or dextrin - in both complex and minimal culture media. The yeast was capable of producing inducible alpha-amylase (EC 3.2.1.1) and glucoamylase (EC 3.2.1.3). The highest level of cell proliferation was observed in the complex medium with glucose. Immobilized cells showed the highest amylolytic activities in culture media with maltose. Both alphaamylase and glucoamylase activities were higher in minimal media than in complex media.
\end{abstract}

Keywords: Debaryomyces occidentalis; encapsulation; foamed alginate; Kluyver effect; alpha-amylase; glucoamylase; ethanol

\section{INTRODUCTION}

Microbial amylases began to be produced on an industrial scale during the last century. They are the most important group of enzymes, in terms of biotechnological applications. In particular, $\alpha$-amylase (1,4- $\alpha$-D-glucan glucanohydrolase, EC 3.2.1.1) and glucoamylase (exo-1,4- $\alpha$-D-glucan glucanohydrolase, EC 3.2.1.3) have found a wide variety of uses in a number of industrial processes, including fermentation, food production and textile and paper manufacturing (Monteiro de Souza and de Oliveira e Magalhães, 2010) Other amylolytic enzymes can bypass the $\alpha-1,6$ branch points in the starch molecule (debranching activity) (Hii et al., 2012). Amylases are produced by a wide range of organisms, including yeasts (Yalçın and Çorbacı, 2013). The main industrial use of amylases is in the starch saccharication process (Hostinová and Gašperík, 2010).

The unconventional yeast Debaryomyces occidentalis (syn. Schwanniomyces occidentalis) was identified as early as the 1980s as a 'super yeast' because of its ability to hydrolyze whole starch to glucose completely without prior hydrolysis (Wang et al., 1999). The ability of Debaryomyces spp. to tolerate extreme stress could be an additionally advantage in low-cost fermentation processes (Johnson and Echavarri-Erasun, 2011). However, D. occidentalis exhibits the Kluyver effect for maltose and starch (Weusthuis et al., 1994). Fermentation of maltose and starch is blocked under anaerobic conditions. This effect may be caused by the rapid down-regulation of sugar carrier capacity, which occurs under oxygenlimited conditions, since certain yeasts require oxygen to transport sugars into their cells and to produce extracellular amylases (Barnett and Entian, 2005) Kluyver effect positive yeasts play an important role in the study of immobilized cells, as they provide a specific indicator for the availability of oxygen within alginate beads.

This study is the continuation of previous research on yeast immobilization, in which Debaryomyces spp. cells were grown inside foamed alginate beads withou undergoing irreversible structural changes to their Ca-alginate networks (Kregie et al., 2013). These results suggested a further avenue of enquiry, into amylolytic activity and ethanol formation in Kluyver-positive yeast cells encapsulated in foamed alginate. This manuscript describes the continuation of previous research, with a special focus on two enzymes: alpha-amylase and glucoamylase. The formation of ethanol, as the end product of yeast fermentation, is also discussed.

\section{MATERIAL AND METHODS}

\section{Yeast strain and culture conditions}

The study used amylolytic yeast Debaryomyces occidentalis Y500/5 from the LOCK105 Culture Collection (Lodz University of Technology, Poland). The strain was maintained on wort agar slants (MERCK-MILLIPORE) and cultured in $50 \mathrm{~mL}$ of complex medium [yeast extract (DIFCO) $2.5 \mathrm{~g} / \mathrm{L}$, peptone Bacto (DIFCO) $5 \mathrm{~g} / \mathrm{L}]$ with $10 \mathrm{~g} / \mathrm{L}$ of D-glucose (SIGMA), maltose (SIGMA), corn starch (SIGMA) or corn dextrin (SIGMA) in $500 \mathrm{~mL}$ round bottom flasks at 25 ${ }^{\circ} \mathrm{C}$ on a rotary shaker (HEIDOLPH) at $220 \mathrm{rpm}$. For the purposes of the experiment, after cultivation the cells were washed twice using Ringer solution (MERCK-MILLIPORE) with centrifugation $(2000 \times \mathrm{g}, 10 \mathrm{~min}, 4 \mathrm{oC})$. The concentration of yeast cells was determined using a haemocytometer, BX41 (OLYMPUS) microscope and a digital camera.

The immobilized yeast cells were cultivated in $50 \mathrm{~mL}$ of complex medium with a carbon source (D-glucose, maltose, corn starch or corn dextrin). The incubation was conducted on a laboratory shaker (HEIDOLPH) under aerobic condition with constant gentle agitation $(120 \mathrm{rpm})$ at $25{ }^{\circ} \mathrm{C}$ for 5 days. After 5 days of incubation inside foamed cores, the immobilized cells (100 beads) were gently washed using sterile distilled water and transferred into $100 \mathrm{~mL}$ of new rich medium YP [yeast extract (DIFCO) $2.5 \mathrm{~g} / \mathrm{L}$, peptone (DIFCO) $5 \mathrm{~g} / \mathrm{L}$ ] or fermentation performance of the immobilized cells $\left[\left(\mathrm{NH}_{4}\right)_{2} \mathrm{SO}_{4} 3 \mathrm{~g} / \mathrm{L} ; \mathrm{KH}_{2} \mathrm{PO}_{4}\right.$ $\mathrm{g} / \mathrm{L}, \mathrm{MgSO}_{4} \cdot 7 \mathrm{H}_{2} \mathrm{O} 0.5 \mathrm{~g} / \mathrm{L}$, yeast extract (DIFCO) $\left.0.5 \mathrm{~g} / \mathrm{L}, \mathrm{CaCO}_{3} 3 \mathrm{~g} / \mathrm{L}\right]$ with a carbon source $(1 \%)$ : glucose $(\mathrm{G})$, maltose $(\mathrm{M})$, natural starch from wheat $(\mathrm{S})$ with $80 \%$ amylopectin and 20\% amylose (MERCK-MILLIPORE) or dextrin from corn (D) (SIGMA). They were then incubated at $25{ }^{\circ} \mathrm{C}$ for 5 days on a rotary shaker $(120 \mathrm{rpm})$. Samples were collected from each culture media, centrifuged $\left(2000 \times \mathrm{g}, 10 \mathrm{~min}, 4{ }^{\circ} \mathrm{C}\right)$ and the supernatants analyzed to determine both amylolytic activity and ethanol production.

\section{Encapsulation}

The traditional liquid-droplet-forming method was used, but from foamed alginate solution. Alginic acid salt from the brown algae was purchased from FLUKA (art. no. 71238). The specifications of this product are the most suitable for immobilization of microorganisms: molecular weight $100000 \div 200000, \mathrm{pH}$ (1\% in water) $6,0 \div 7,5$ (Blandino et al., 2001). The inoculum cells were centrifuged and suspended in $0.85 \% \mathrm{NaCl}$ solution. To this solution was added (1:1) sodium alginate gel ( $4 \% \mathrm{w} / \mathrm{w}$, FLUKA), which had been foamed by adding 
$0.1 \%$ Triton X-100 (MERCK-MILLIPORE). Triton X-100 was used as the foaming agent in a novel procedure. The toxicity of this compound was verified at the beginning of this research on foamed alginate (unpublished data). This compound at a concentration of $0.01 \%$ did not show any toxicity towards yeasts. Only chemicals of the highest purity were used. The solutions and materials were sterilized before use at $121{ }^{\circ} \mathrm{C}$, except for the sodium alginate solution which was sterilized using tyndallization. The mixture, which contained around $1 \times 10^{4}$ cells per $1 \mathrm{~mL}$ of gel, was dropped through a $1.8 \mathrm{~mm}$ needle into $0.15 \mathrm{M} \mathrm{CaCl}_{2}$ solution. The beads $(\phi \sim 3 \mathrm{~mm})$ were hardened in $0.15 \mathrm{M} \mathrm{CaCl}_{2}$ solution for 60 minutes and then washed in distilled water $(5 \mathrm{~min})$. To study the internal morphology beads were frozen $\left(-20^{\circ} \mathrm{C}\right)$ and cut with a sharp razor blade. Slices of alginates were observed under a light microscope CX41 (OLYMPUS). The procedure for creating the foamed gels was described in Polish Patent No. 210458 (Ambroziak et al., 2012). The resultant cores of foamed alginate consisted of micro-spheres approximately 50-200 microns in diameter and had a specific internal bubble structure (Fig. 1). The foamed beads were vented inside a sterile syringe under a mild vacuum at $10{ }^{\circ} \mathrm{C}$ for 24 hours in a liquid complex medium with glucose, maltose, starch or dextrin, in order to introduce nutrients into the bead spheres. To increase mechanical stability, the foamed beads were given an additional alginate coating by placing them in a solution of 3\% alginate (FLUKA) for 15 minutes. They were then washed in sterile water (Kregiel $\boldsymbol{e t}$ al., 2013)

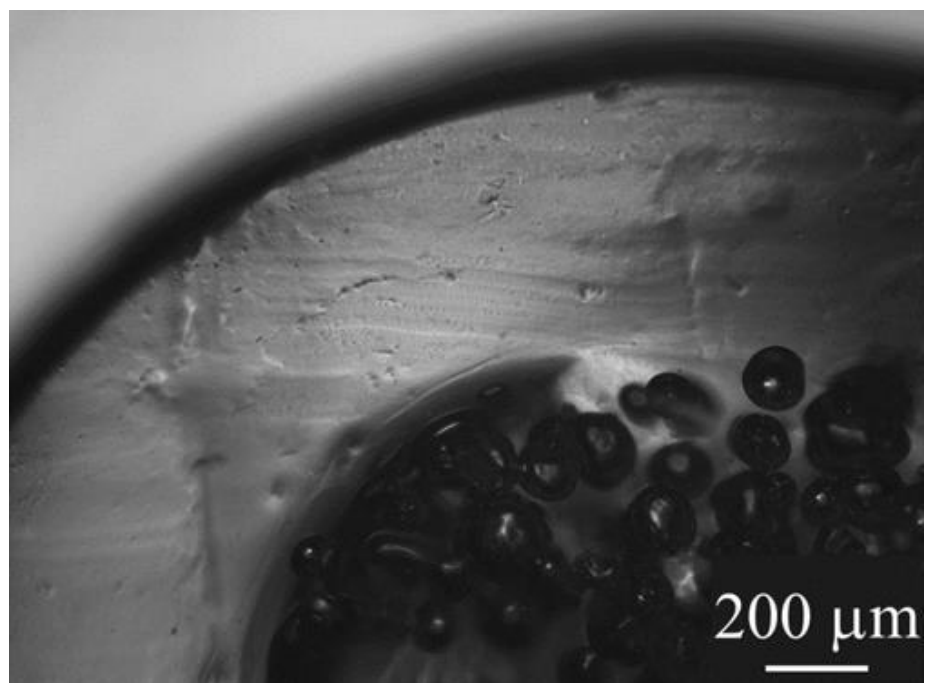

Figure 1 Internal foamed structure of alginate bead and additional alginate coating

A quantitative assessment of the immobilization was performed by dissolving the alginate beads in $0.2 \mathrm{M} \mathrm{Na}_{2} \mathrm{HPO}_{4}$ (in a ratio of 1 bead per $1 \mathrm{~mL}$ ). The number of immobilized cells was determined using the microscopic method. The number of cells per single tested bead was calculated and presented as a logarithmic function.

\section{Amylolytic and fermentation activities}

Alpha-amylase activity was estimated using the 3,5-dinitrosalicylic acid method on the basis of the amount of reducing sugars released during starch hydrolysis (Damián-Almazo et al., 2008). The reaction was carried out in $1 \mathrm{ml}$ of 10 $\mathrm{mg} / \mathrm{mL}$ soluble starch from corn (73\% amylopectin and 27\% amylose) (SIGMA) dissolved in $50 \mathrm{mM} \mathrm{KH}_{2} \mathrm{PO}_{4}-\mathrm{NaOH}$ buffer $(\mathrm{pH}=6.0)$ at $45^{\circ} \mathrm{C}$ for 10 minutes. One unit of enzyme activity was defined as the amount of maltose equivalents $(\mu \mathrm{mol})$ released per minute and per $\mathrm{mL}$ of supernatant (Moranelli et al. 1987; Ryu and Sung, 1993).

Glucoamylase activity was determined from the reaction of $1 \mathrm{~mL}$ supernatant (after cultivation in $1 \mathrm{ml}$ of $10 \mathrm{mg} / \mathrm{mL}$ soluble starch from corn (SIGMA) in 50 $\mathrm{mM}$ citrate buffer $(\mathrm{pH}=5)$ at $50{ }^{\circ} \mathrm{C}$ for $20 \mathrm{~min}$. The glucose released was measured using 3,5-dinitrosalicylic acid reagent with glucose as a standard. One glucoamylase activity unit (U) was defined as the amount of enzyme that releases one $\mu \mathrm{mol}$ of glucose equivalent per minute per $\mathrm{mL}$ (Clementi and Rossi 1986; Ryu and Sung, 1993).

The fermentation performance of the immobilized cells was evaluated based on the ethanol content in the precipitate, determined using an AGILENT 6890 gas chromatograph equipped with headspace autosampler, capillary INNOVAX column $(60 \mathrm{~m} \times 0.32 \mathrm{~mm})$ and flame ionization detector (FID) (Kregiel et al., 2012)

The experiments were carried out in triplicate, and the standard deviation was calculated.

\section{RESULTS AND DISCUSSION}

\section{Yeast cell growth inside gel beads}

After a 5-day incubation period in complex medium with glucose YPD, the number of immobilized yeast cells increased from an initial $2 \times 10^{4}$ to $1.2 \times 10^{7}$ per bead, indicating significant colonization of the alginate cores (Fig. 2). Multiplication inside beads incubated in complex media with other carbon sources was slightly lower at $5 \div 6 \times 10^{6}$ cells $/$ bead.

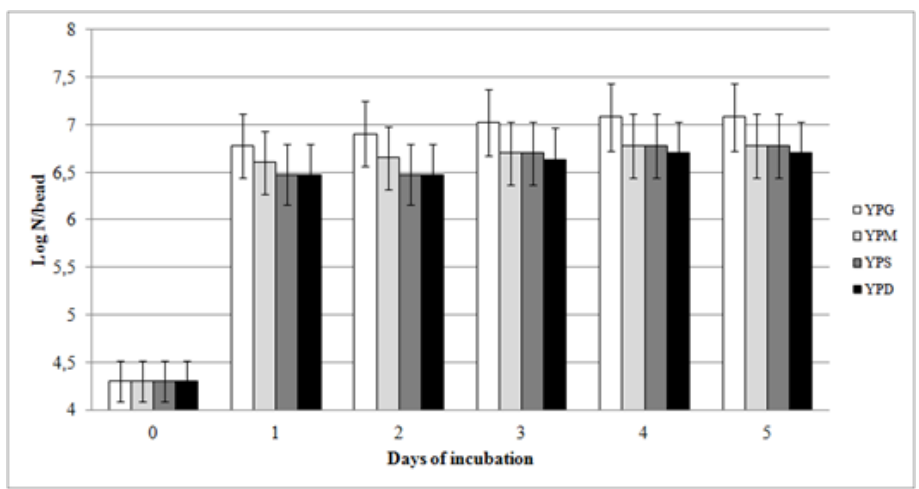

Figure 2 Growth of Debaryomyces occidentalis in foamed alginate beads

Oxygen may influence the production of glycolytic enzymes (Fukuhara, 2003) Violle et al. (1992) have shown that amylase and glucosidase are not synthetized in the presence of maltose under anaerobic conditions. However, maltose permease is synthetized in anaerobiosis without its functioning being inhibite. In our studies, foamed alginate cores with special interior spaces provided favorable conditions for the synthesis of amylolytic enzymes.

The alpha-amylase activity in rich culture media gradually increased, reaching the highest value $(2.65 \mathrm{U} / \mathrm{mL})$ in YPM medium with maltose as the carbon source (Fig. 3A). No such gradual increase in alpha-amylase activity was observed during the cultivation of immobilized yeast cells in minimal medium Mo, although the highest value of alpha-amylase activity was again in the medium with maltose as the carbon source (3.9 U/mL) (Fig. 3B).

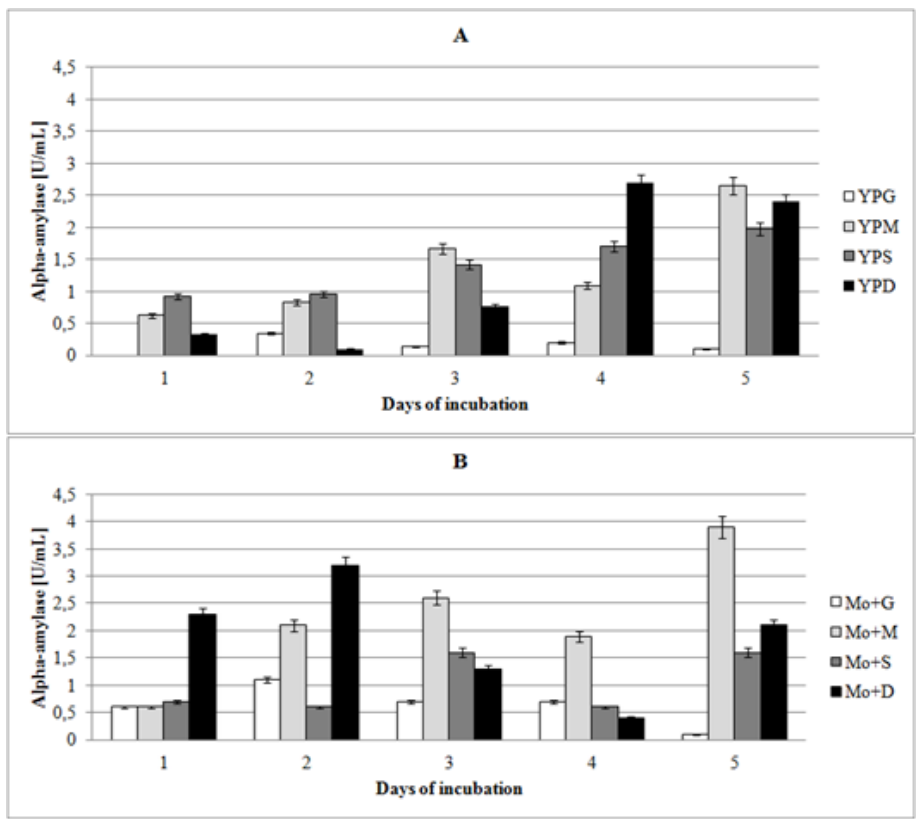

Figure 3 Alpha-amylase activity in A) complex medium, B) minimal medium

The maximal activities of glucoamylase were also noted in culture media with maltose, at $0.08 \mathrm{U} / \mathrm{mL}$ and $0.11 \mathrm{U} / \mathrm{mL}$ for rich and minimal medium, respectively (Fig. 4 AB) 


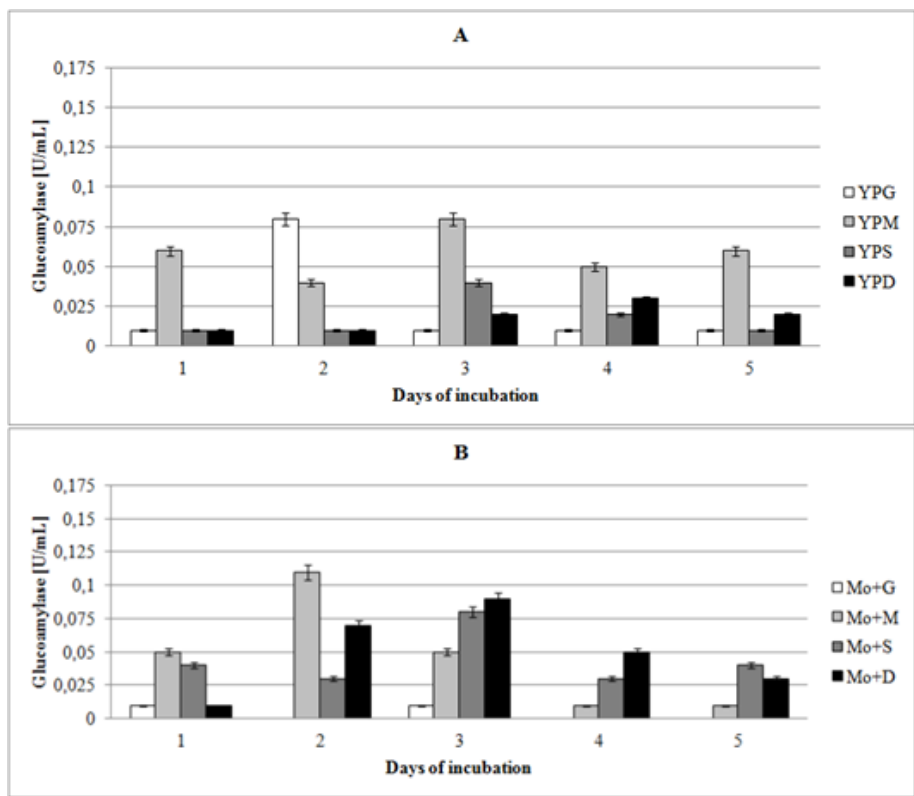

Figure 4 Glucoamylase activity in A) complex medium, B) minimal medium

These results confirm that amylases show substrate specificity, and that the production of amylolytic enzymes is subject to catabolite repression by glucose (Gupta et al., 2003).

Amylolytic activity was detected in the culture media throughout the cultivation period, except in the media with glucose as a carbon source. This may be due to the high stability of these enzymes. Flores-Maltos et al. (2011) have found that cross-linking the alginate with divalent ions (such as $\mathrm{Ca}^{2}+$ ) improves the stability of enzymes. Figure 5 shows that immobilized D. occidentalis produced ethanol with different carbon sources.

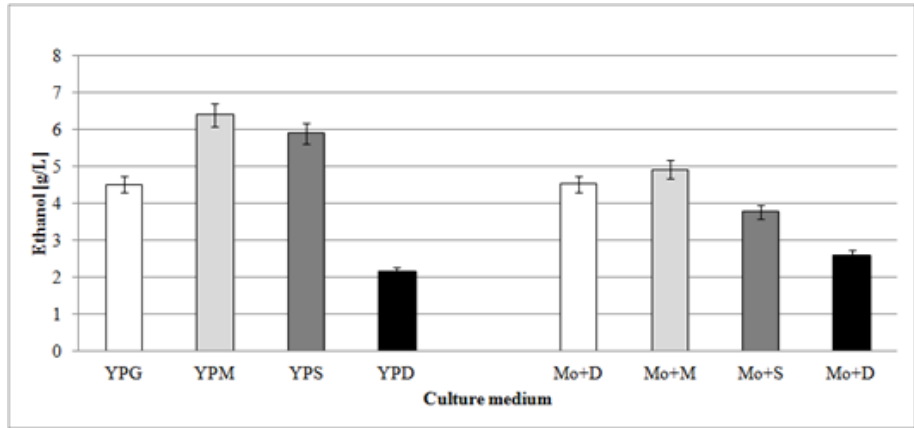

Figure 5 Ethanol formation by encapsulated yeast

The highest levels of ethanol production were obtained in YPM and Mo medium with maltose, at 6.4 and $4.9 \mathrm{~g} / \mathrm{L}$, respectively. These results indicate that in the foamed alginate cores with Kluyver-positive cells, takes place not only the synthesis of amylolytic enzymes, but also alcohol fermentation in one-step process. These and previously reported data (Kregiel et al., 2013) shows that yeast encapsulation in foamed alginate seems to have an excellent potential for inexpensive, low energy and repeatable process of starch hydrolysis.

\section{CONCLUSION}

The method of cell encapsulation in foamed alginate presented in this paper allows not only for good growth of Kluyver-positive yeast within the bead spaces, but also for the production of amylases, using various carbon sources This immobilization technique may be an effective way to produce stable amylolytic enzymes, which are of great scientific interest and have a broad range of industrial applications.

Acknowledgments: This research was supported by the Polish Ministry for Science and Information Technology 2PO6T08129.

\section{REFERENCES}

Ambroziak, W., Kregiel, D., Dziedziczak, K., Rosiak, J., Kolodziejczyk, M (2012). Polish Patent No. 210458 'The manner of locking of yeast cells.' Journal of Patent Office of the Republic of Poland, 1. ISSN - 0043 - 5201.

Barnett, J. A., \& Entian, K. D. (2005). A history of research on yeasts 9 regulation of sugar metabolism. Yeast, 22(11), 835-894. http://dx.doi.org/10.1002/yea.1249
Blandino, A., Macias, M., \& Cantero, D. (2001). Immobilization of glucose oxidase within calcium alginate gel capsules. Process Biochemistry, 36, 601-606. http://dx.doi.org/10.1016/S0032-9592(00)00240-5

Barnett, J. A., \& Entian, K. D. (2005). A history of research on yeasts 9 : regulation of sugar metabolism. Yeast, 22(11), 835-894. http://dx.doi.org/10.1002/yea.1249

Clementi, F., \& Rossi, J. (1986). Alpha-amylase and glucoamylase production by Schwanniomyces castellii. Antonie van Leeuwenhoek, 52(4), 343-52. http://dx.doi.org/10.1007/bf00428645

Damián-Almazo, J. Y., Moreno, A., López-Munguía, A., Soberón, X., GonzálezMuñoz, F., \& Saab-Rincón, G. (2008). Enhancement of the alcoholytic activity of $\alpha$-amylase amyA from Thermotoga maritime MSB8 (DSM 3109) by site-directed mutagenesis. Applied and Environmental Microbiology, 74(16), 5168-5177. http://dx.doi.org/10.1128/aem.00121-08

Flores-Maltos, A., Rodríguez-Durán, L.V., Renovato, J., Contreras, J.C Rodríguez, R., \& Aguilar, C. N. (2011) Catalytical properties of free and immobilized Aspergillus niger Tannase. Enzyme Research. Article ID 768183 http://dx.doi.org/10.4061/2011/768183

Fukuhara, H. (2003). The Kluyver effect revisited. FEMS Yeast Research, 3(4), 327-331. http://dx.doi.org/10.1016/s1567-1356(03)00112-0

Gupta, R., Gigras, P., Mohapatra, H., Goswami, V. K., \& Chauhan, B. (2003). Microbial $\alpha$-amylases: a biotechnological perspective. Process Biochemistry, 38(11), 1599-1616. http://dx.doi.org/10.1016/s0032-9592(03)00053-0

Hii, S. L., Tan, J. S., Ling, T. C., \& Ariff, A. B. (2012). Pullulanase: role in starch hydrolysis and potential industrial applications. Enzyme Research. Article ID 921362. http://dx.doi.org/10.1155/2012/921362

Hostinová, E., \& Gašperík, J. (2010). Yeast glucoamylases: molecular-genetic and structural characterization. Biologia, 65(4), 559-568. http://dx.doi.org/10.2478/s11756-010-0077-8

Johnson, E. A., \& Echavarri-Erasun, C. (2011). Yeast biotechnology. In: Kurtzman CP, Fell JW, Boekhout T (eds.) The Yeasts, a Taxonomic Study, 5th edn Elsevier, Amsterdam, pp. 21-44.

Kregiel, D., Berlowska, J., \& Ambroziak, W. (2012). Adhesion of yeast cells to different porous supports, stability of cell-carrier systems and formation of volatile by-products. World Journal of Microbiology and Biotechnology, 28(12), 3399-3408. http://dx.doi.org/10.1007/s11274-012-1151-x

Kregiel, D., Berlowska, J., \& Ambroziak, W. (2013) Growth and metabolic activity of conventional and non-conventional yeasts immobilized in foamed alginate. Enzyme Microbiology and Technology, 53(4), 229-234. http://dx.doi.org/10.1016/i.enzmictec.2013.05.010

Monteiro de Souza, P., \& de Oliveira e Magalhães, P. (2010). Application of microbial $\alpha$-amylase in industry - A review. Brazilian Journal of Microbiology. http://dx.doi.org/10.1590/S1517-83822010000400004

Moranelli, F., Yaguchi, M., Calleja, G. B., \& Nasim, A. (1987). Purification and characterization of the extracellular alpha-amylase activity of the yeast Schwanniomyces alluvius. Biochemistry and Cell Biology, 65(10), 899-908.

Ryu, Y. W., \& Sung, H. K. (1993). Selective isolation and characterization of Schwanniomyces castellii mutants with increased production of alpha-amylase and glucoamylase. Journal of Microbiology and Biotechnology, 3(2), 95-98 http://dx.doi.org/10.1007/bf00428645

Violle, P., Boze, H., Moulin, G., \& Galzy, P. (1992). Transport and hydrolysis of maltose by Schwanniomyces castellii. Journal of Basic Microbiology, 32(1), 57 63. http://dx.doi.org/10.1002/jobm.3620320117

Wang, T. T., Lee, Ch. F., \& Lee, B. H. (1999). The molecular biology of Schwanniomyces occidentalis Klocker. Critical Reviews of Biotechnology, 19(2), 113-143. http://dx.doi.org/10.1080/0738-859991229215

Weusthuis, R. A., Luttik, M. A., Scheffers, W. A., van Dijken, J. P., \& Pronk, J. T. (1994). Is the Kluyver effect in yeasts caused by product inhibition? Microbiology, 140(7), 1723-1729. http://dx.doi.org/10.1099/13500872-140-7 1723

Yalçın, H. T., \& Çorbacı, C. (2013). Isolation and characterization of amylase producing yeasts and improvement of amylase production. Turkish Journal of Biochemistry, 38(1), 101-108. http://dx.doi.org/10.5505/tjb.2013.95866 